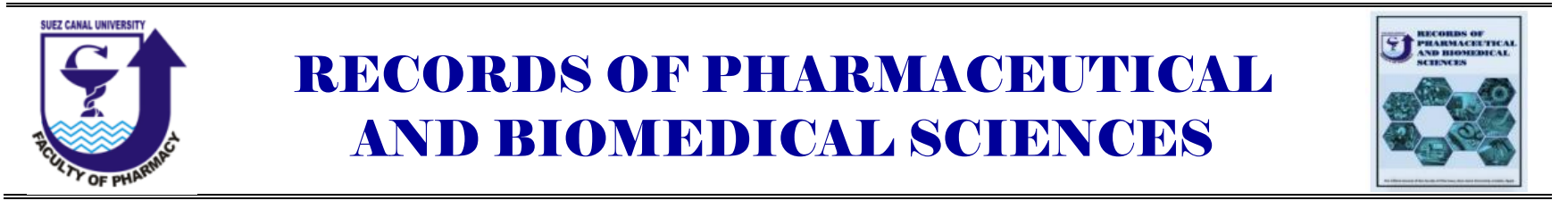

\title{
The potential antioxidant and anti-inflammatory effects of catechins polyphenolic compounds in tea and cocoa extracts on STZ diabetic rats
}

\author{
Omayma M. El-Darder ${ }^{a}$, Dina M. Abo-Elmatty, Asmaa R. Abdel-Hamed ${ }^{b} *$ \\ ${ }^{a}$ Department of Home Economics, Faculty of Education, Suez Canal University, Ismailia, Egypt \\ ${ }^{b}$ Department of Biochemistry, Faculty of Pharmacy, Suez Canal University, Ismailia, Egypt.
}

Received on: 11. 06. 2020

Revised on: 25. 06. 2020

Accepted on: 28. 06. 2020

Correspondence Author:

Tel: +201227009257

E-mail address:

asmaa.ramdan@pharm.suez.edu.eg

\begin{abstract}
The aim of this study is to investigate the effect of some phenolic compounds such as catechines that heavily present in tea and cocoa extracts against diabetic induction using streptozotocin (STZ) treated rats. Eighty male albino rats were divided into eight groups of ten rats each as follows; normal, black tea, green tea, cocoa, STZ- diabetic, STZ- diabetic + black tea, STZ- diabetic + green tea, STZ- diabetic + cocoa. Blood glucose, glycosylated hemoglobin, serum insulin and lipid profile were assessed in all groups. In addition, HOMA-IR and atherogenic index were calculated. Further, inflammatory markers and other metabolic parameters such as endothelial dysfunction and oxidative stress markers were estimated. The data showed that all the used extracts had antioxidant and anti-inflammatory effect against STZ induced diabetes. Although, green tea extract showed the maximum improvement in antioxidants levels and cocoa extract showed the maximum improvement in inflammatory markers. We concluded that tea and cocoa extracts had a protective effect against STZ induced diabetes which attributed to their free radical scavenging antioxidants that reduced both the production and release of inflammatory markers.
\end{abstract}

Keywords: Diabetes, Streptozotocin, Catechins

\section{Introduction}

Diabetes mellitus is a metabolic disorder and is considered one of the major causes of morbidity and mortality worldwide (Bhardwaj et al., 2014). The World Health Organization estimated that more than 176 million people globally suffering from type 2 diabetes mellitus (non-insulin dependent diabetes mellitus). So, type 2 diabetes mellitus has become a global health problem (Jaiswal et al., 2016). Several microvascular and macrovascular complications are developed during diabetes and this is due to the enhanced generation of free radicals, oxidative stress and deficiency of endogenous antioxidants (Rahimi et al., 2005). Streptozotocin or streptozocin (STZ) is a synthetic antineoplastic agent that is used for treating certain cancers of the islets of Langerhans in mammals due to its cytotoxic effect on the insulin producing $\beta$-cells of the pancreas. Moreover, in scientific research, STZ is used for inducing insulitis and diabetes on experimental 
animals because of its high toxicity to $\beta$-cells of the pancreas (Rossini et al., 1977). Metformin, sulfonylureas, meglitinides, thiazolidinediones and insulin are examples of medications used for treatment of type 2 diabetes mellitus. Recent studies proposed an alternative tools for the management of diabetic complications like the inclusion of antioxidants in diet or as a medicine. The plant kingdom offers an untapped source of antioxidant agents (Dey et al., 2011; Bhattacharya, 2017). Many studies illustrated that polyphenolic compounds can prevent type 2 diabetes mellitus (Montonen et al., 2004; Bahadoran et al., 2013). The copious presence of polyphenols in our diet in addition to their low toxicity recommended them to protect health against oxidative stress and accordingly diabetes mellitus (Pandey and Rizvi, 2009). Tea and cocoa are food sources rich in phenolic compounds which have many important functions including antioxidant, antimutagenic and antitumor activities (Othman et al., 2007). Catechin is a well known polyphenol secondary metabolite occurring in many plants (Figure 1) with $(+)$-catechin being the most common isomer, the other is (-)-catechin that can be distinguished using chiral column chromatography (Rinaldo et al., 2010). Many plants and fruits such as apples, kiwi, blueberries, grape seeds and strawberries are rich with catechin. Additionally, green tea, cacao liquor, chocolate and cocoa are excellent sources of catechin (Figures 2 and 3). Levels varied to a large extent from $4.5 \mathrm{mg} / \mathrm{kg}$ in kiwi fruit to $610 \mathrm{mg} / \mathrm{kg}$ in black chocolate (Arts et al., 2000). Catechin has an antioxidant action that is well determined by different in vitro, in vivo and physical methods (Yilmaz, 2006). In the present work, we evaluate the antioxidant and anti-inflammatory effect of catechin in tea and cocoa extracts on STZ- diabetic rats.

\section{Materials and methods}

\subsection{Animals and experimental design}

Eighty adult male albino rats weighing 180-200 g obtained from the animal house of National Research Center, Giza, Egypt, were used in this study. Rats were maintained under controlled room temperature $(25 \pm 3)$ and normal light-dark cycle with free access to food and water throughout the experiment and were left one week for acclimatization. Rats were divided into eight groups of ten rats each as follows:
Group 1 (normal control): healthy rats received normal saline $(1 \mathrm{ml} / \mathrm{kg} / \mathrm{day})$ orally for thirty days.

Group 2 (black tea group): healthy rats received black tea extract (36 mg/rat twice a day) orally for thirty days (Majchrzak et al., 2004).

Group 3 (green tea group): healthy rats received green tea extract (36 mg/rat twice a day) orally for thirty days (Majchrzak et al., 2004).

Group 4 (cocoa group): healthy rats received cocoa extract (36 mg/rat twice a day) orally for thirty days (Majchrzak et al., 2004).

Group 5 (diabetic control group): STZ-diabetic rats.

Group 6 (STZ-diabetic + black tea group): STZdiabetic rats received black tea extract $(36 \mathrm{mg} / \mathrm{rat}$ twice a day) orally for thirty days.

Group 7 (STZ-diabetic + green tea group): STZdiabetic rats received green tea extract $(36 \mathrm{mg} / \mathrm{rat}$ twice a day) orally for thirty days.

Group 8 (STZ-diabetic + cocoa group): STZdiabetic rats received cocoa extract $(36 \mathrm{mg} / \mathrm{rat}$ twice a day) orally for thirty days.

Experimental animals were kept and used in accordance with the Guide for the Care and Use of Laboratory Animals (National Research Council, 2011). All experimental protocols were approved by the Ethics Committee at the Faculty of pharmacy, Suez Canal University (Ismailia, Egypt) (code \# 201904RA2).

\subsection{Plant extraction}

Green tea, black tea and cocoa products were purchased from Egyptian market. Two g of each product were extracted with $100 \mathrm{~mL}$ of water at a temperatures of $80{ }^{\circ} \mathrm{C}$ for $30 \mathrm{~min}$ (Vuong et al., 2011).<smiles>Oc1cc(O)c2c(c1)O[C@H](c1ccc(O)c(O)c1)[C@H](O)C2</smiles>

Figure 1: chemical structure of catechin 

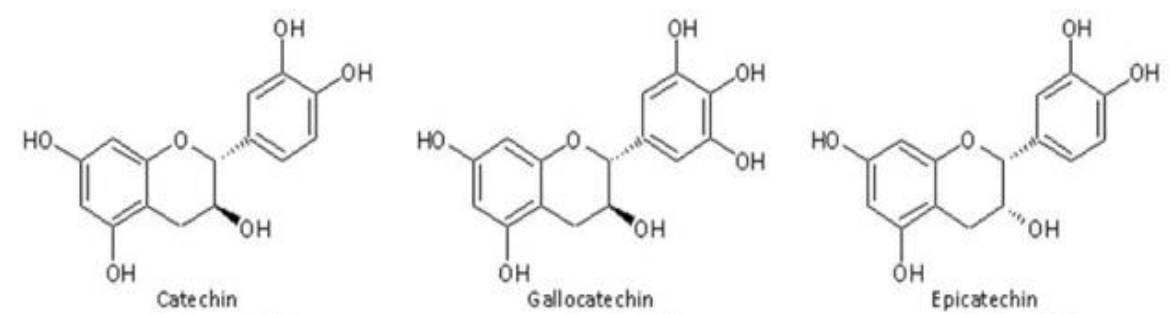<smiles>Oc1cc(O)c2c(c1)O[C@H](c1cc(O)c(O)c(O)c1)[C@H](O)C2</smiles><smiles>O=C(O[C@@H]1Cc2c(O)cc(O)cc2O[C@H]1c1ccc(O)c(O)c1)c1cc(O)c(O)c(O)c1</smiles>

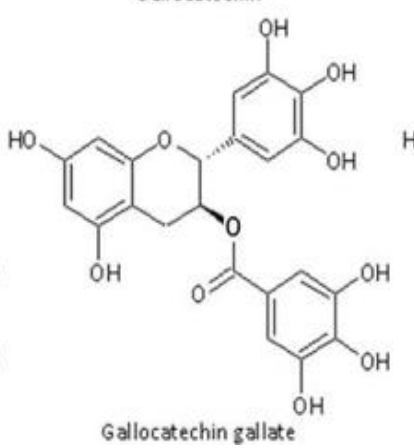<smiles>O=C(O[C@H]1Cc2c(O)cc(O)cc2O[C@@H]1c1ccc(O)c(O)c1)c1cc(O)c(O)c(O)c1</smiles><smiles>O=C(O[C@H]1Cc2c(O)cc(O)cc2O[C@H]1c1cc(O)c(O)c(O)c1)c1cc(O)c(O)c(O)c1</smiles>

Figure 2: Structures of the catechins of green tea (Wein et al., 2016)

\subsection{Experimental induction of type 2 diabetes mellitus by high fat diet and low- dose STZ}

The rats were allocated into two dietary regimens; 40 rats (groups 1, 2, 3 and 4) fed normal palatable diet (NPD; $12 \%$ calories as fat) and 40 rats (groups 5, 6, 7 and 8) fed high fat diet (HFD; 58\% calories as fat) (Reed et al., 2000). The composition of HFD was described by (Srinivasan et al., 2005). After the two weeks of dietary manipulation, 40 rats fed HFD, were injected intraperitoneally (i.p) with STZ $35 \mathrm{mg} / \mathrm{kg}$ (Srinivasan et al., 2005) dissolved in disodium citrate buffer ( $\mathrm{pH} 4.5)$ as a single dose. After ten days from STZ administration, blood samples were obtained from tail tip and then glucose level was measured using glucometer method (Accutrenr alpha-Boehringer Mannheim). Only rats with fasting blood glucose level (250-300 $\mathrm{mg} / \mathrm{dl}$ ) were enrolled in the study (Algandaby et al., 2010).

\subsection{Blood Sampling and Biochemical Analysis}

Blood samples were collected from the tail vein. Serum and plasma were separated and kept at -80 ${ }^{\circ} \mathrm{C}$ until performing the biochemical measurements. Glycosylated hemoglobin (HbA1c) was determined using Glyco-Tek Affinity column kits and reagents according to the manufacturer's instructions. Serum glucose level was measured according to the method of (Trinder, 1969) by the enzymatic colorimetric method (Biodiagnostic, Egypt), lipid profile including serum triglycerides (TG), total cholesterol (TC) and high-density lipoprotein cholesterol (HDL-C) were measured by enzymatic colorimetric methods according to (Fossati and Prencipe, 1982), (Allain et al., 1974) and (LopesVirella et al., 1977) respectively using Biodiagnostic kits, Egypt, and low-density lipoprotein cholesterol (LDL-C) was calculated according to the method of Friedewald et al., (1972). Additionally, atherosclerosis index was calculated using specific formula, atherosclerosis index $=($ serum TC - HDL-C) $/$ HDL-C (Chen et al., 2010). Homeostasis Model Assessment-Insulin Resistance (HOMA-IR) was also calculated by the equation: (Glucose $\mathrm{x}$ insulin) / 405, where serum fasting glucose concentration is given in $\mathrm{mg} / \mathrm{dl}$ and serum fasting insulin level is given in $\mu \mathrm{IU} / \mathrm{ml}$, a high HOMA index denotes low insulin sensitivity (Matthews et al., 1985).

Acute phase reactants such as C-Reactive Protein (CRP) and Serum Amyloid A (SAA) and proinflammatory cytokines such as Tumor Necrosis Factor alpha (TNF- $\alpha$ ) and Interleukin 6 (IL-6) levels were assessed in the serum using enzymelinked immunosorbent assay (ELISA) kits according to the manufacturer's instructions.

Preparation of rings of rat thoracic aorta was performed according to Wang et al., (1998). Then detection of superoxide anion was estimated 


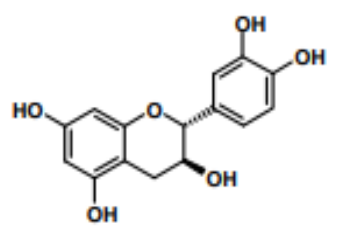

(*)-Catechin (2R, 3S)<smiles>Oc1cc(O)c2c(c1)OC(c1ccc(O)c(O)c1)C(O)C2</smiles>

(-)-Catechin (2S, 3R)<smiles>Oc1cc(O)c2c(c1)OC(c1ccc(O)c(O)c1)C(O)C2</smiles>

(-)-Epicatechin (2R, 3R)<smiles>Oc1cc(O)c2c(c1)OC(c1ccc(O)c(O)c1)C(O)C2</smiles>

(+)-Epicatechin (2S, 3S)<smiles>Oc1ccc(C2c3c(O)cc(O)cc3OC(c3ccc(O)c(O)c3)C2O)c(O)c1</smiles>

Procyanidin B2

Figure 3: Structures of the catechins of cocoa (Kofink et al., 2007)

according to Auclair et al., (1978); Pourcyrous et al., (1993); Musleh et al., (1994); Doctrow et al., (1997).

Oxidized LDL-C (oxLDL-C) was performed by the method described by Ohkawa et al. (1979). The absorbance was measured at $532 \mathrm{~nm}$. The thiobarbituric acid reactive substances (TBARS) concentrations were calculated using a standard curve for $1,1^{\prime}, 3,3^{\prime}$-tetraethoxypropane $\left(10^{-4} \mathrm{~mol} / \mathrm{L}\right)$ and were expressed as $\mu \mathrm{mol}$ of malondialdehyde (MDA) per milligram of protein.

Serum nitric oxide (NO) concentrations were determined with the Greiss reaction by measuring combined oxidation products of nitric oxide, serum nitrate and nitrate after reduction with nitrate reductase (Bryan and Grisham, 2007).

\subsection{Statistical Analysis}

Data were managed using the Statistical Package for Social Sciences (SPSS Inc., Chicago, IL), version 17.0 software. The results were expressed as mean $\pm \mathrm{SD}$. One-way analysis of variance, ANOVA, followed by Bonferroni's multiple comparisons test were employed for statistical analysis. A value of $p \leq 0.05$ was considered to be statistically significant.

\section{Results}

Serum glucose and glycosylated hemoglobin (HbA1c) levels were significantly increased in STZ-diabetic control group compared to normal control group $(P<0.05)$. Although, these levels were significantly decreased in all treated groups (black tea, green tea and cocoa) compared to STZdiabetic control group $(P<0.05)$ (Table 1$)$. In addition, serum insulin was significantly decreased in STZ-diabetic control group compared to normal control group $(P<0.05)$ and significantly increased in all treated groups (black tea, green tea and cocoa) compared to STZ-diabetic control group $(P<0.05)$. The calculated HOMA-IR index which estimates the $\beta$-cell 
Table 1: Effect of black tea, green tea and cocoa extracts on fasting serum levels of glucose, insulin, \% HbA1C and HOMA-IR index in all groups.

\begin{tabular}{lcccc}
\hline Groups & $\begin{array}{c}\text { Serum glucose } \\
(\mathbf{m g} / \mathbf{d l})\end{array}$ & $\begin{array}{c}\text { Serum insulin } \\
(\boldsymbol{\mu U} / \mathbf{m L})\end{array}$ & \%HbA1c & HOMA-IR \\
\hline Normal control & $97.2 \pm 14.4$ & $12.2 \pm 2.5$ & $8.1 \pm 3.2$ & $3.2 \pm 0.7$ \\
Black tea & $99.5 \pm 21.5$ & $12.3 \pm 2.4$ & $8.2 \pm 2.6$ & $3.4 \pm 0.65$ \\
Green tea & $93.5 \pm 24.6$ & $12 \pm 2.6$ & $7.8 \pm 1.9$ & $3.1 \pm 0.32$ \\
$\quad$ Cocoa & $91.5 \pm 18.6$ & $12 \pm 2.9$ & $8.2 \pm 2.2$ & $3.3 \pm 0.67$ \\
Diabetic control & $301 \pm 62.0^{\#}$ & $7.7 \pm 2.05^{\#}$ & $15 \pm 4.5^{\#}$ & $6.2 \pm 0.55^{\#}$ \\
STZ-diabetic + & $208 \pm 39.1^{*}$ & $10.4 \pm 3.7^{*}$ & $12 \pm 4.5^{*}$ & $4.9 \pm 0.65^{*}$ \\
$\quad$ Black tea & & & $11 \pm 4.2^{*}$ & $4.3 \pm 0.32^{*}$ \\
$\quad \begin{array}{c}\text { STZ-diabetic }+ \\
\quad \text { Green tea }\end{array}$ & $225 \pm 27.9^{*}$ & $9.4 \pm 2.5^{*}$ & & \\
$\quad$ & & $13 \pm 4.1^{*}$ & $4.4 \pm 0.27^{*}$ \\
$\begin{array}{l}\text { STZ-diabetic }+ \\
\quad \text { Cocoa }\end{array}$ & $189.4 \pm 14.2^{*}$ & $10 \pm 1.8^{*}$ & & \\
\hline
\end{tabular}

Data were represented as mean \pm SD and analyzed using ANOVA followed by Bonferroni's post-hoc test at $p$ value $<0.05$. \# Significantly Different from normal control at $\mathrm{P}<0.05$, * significantly different from diabetic control at $\mathrm{P}<0.05$.

Table 2: Effect of black tea, green tea and cocoa extracts on lipogram pattern in all groups.

\begin{tabular}{cccccc}
\hline Groups & TG $(\mathbf{m g} / \mathbf{d l})$ & TC $(\mathbf{m g} / \mathbf{d l})$ & $\begin{array}{c}\text { HDL-C } \\
(\mathbf{m g} / \mathbf{d l})\end{array}$ & $\begin{array}{c}\text { LDL-C } \\
(\mathbf{m g} / \mathbf{d l})\end{array}$ & Atherogenic index \\
\hline Normal control & $85 \pm 12.6$ & $80.4 \pm 11.1$ & $26 \pm 3.4$ & $60 \pm 13.6$ & $2.07 \pm 0.47$ \\
Black tea & $84.6 \pm 13.9$ & $87.3 \pm 12.4$ & $25.7 \pm 5.8$ & $62 \pm 12.4$ & $2.1 \pm 0.44$ \\
Green tea & $83.8 \pm 13$ & $80.2 \pm 12.5$ & $26.8 \pm 4.9$ & $59 \pm 14.6$ & $2.14 \pm 0.75$ \\
$\quad$ Cocoa & $86.9 \pm 15$ & $81.7 \pm 13.2$ & $26.3 \pm 5$ & $61 \pm 13.5$ & $2.3 \pm 0.57$ \\
$\begin{array}{c}\text { Diabetic control } \\
\text { STZ-diabetic }+ \\
\quad 146 \pm 24.4^{\#}\end{array}$ & $123 \pm 22.6^{\#}$ & $22.6 \pm 2.6^{\#}$ & $88 \pm 20.7^{\#}$ & $4.2 \pm 1.2^{\#}$ \\
$\begin{array}{c}\text { Black tea } \\
\text { STZ-diabetic }+\end{array}$ & $108 \pm 15.9^{*}$ & $105 \pm 23.7^{*}$ & $25 \pm 4.5$ & $65 \pm 14.5^{*}$ & $2.9 \pm 0.8^{*}$ \\
$\quad \begin{array}{l}\text { Green tea } \\
\text { STZ-diabetic }+\end{array}$ & $100 \pm 10^{*}$ & $108 \pm 29^{*}$ & $24 \pm 3.3^{*}$ & $66 \pm 14.6^{*}$ & $2.7 \pm 1.7^{*}$ \\
$\quad$ Cocoa & $101 \pm 16.1^{*}$ & $23 \pm 3.4^{*}$ & $63 \pm 15.6^{*}$ & $2.5 \pm 1.07^{*}$ \\
\hline
\end{tabular}

Data were represented as mean \pm SD and analyzed using ANOVA followed by Bonferroni's post hoc test at $p$ value $<0.05$. \# Significantly Different from normal control at $\mathrm{P}<0.05$, * significantly different from diabetic control at $\mathrm{P}<0.05$. 
function and insulin resistance was significantly increased in STZ-diabetic control group compared to normal control group $(P<0.05)$ and a significant reduction was observed after treatment with black tea, green tea and cocoa extracts compared to STZdiabetic control group $(P<0.05)$ (Table 1).

Serum lipid profile was significantly affected by STZ-induced diabetes, (Table 2) showed that a significant increase in TG, TC and LDL-C and a significant decrease in HDL-C in STZ-diabetic control group compared to normal control group $(P<0.05)$ and this was significantly reversed after treatment with green tea and cocoa extracts. The calculated atherogenic index was significantly increased in STZ-diabetic control group compared to normal control group $(P<0.05)$ and significantly decreased in all treated groups (black tea, green tea and cocoa) compared to STZ-diabetic control group $(P<0.05)$ (Table 2).

Moreover, serum levels of some inflammatory markers such as CRP, SAA, TNF- $\alpha$ and IL- 6 were significantly increased in STZ-diabetic control group compared to normal control group $(P<0.05)$ while, these levels were significantly reduced after treatment with the three extracts (Table 3). Treatment with cocoa extract was the most effective as there was a significant decrease in the levels of theses inflammatory markers when compared to groups treated with black and green tea extracts (Table 3).

Table 4 revealed that the mean values of aortic superoxide anion production, oxidized LDL-C and NO were significantly increased in STZ-diabetic control group compared to normal control group $(P<0.05)$. However, in treated groups, the mean values were significantly decreased compared to STZ-diabetic control group indicating the reduction of oxidative stress by all the three extracts. Further, treatment with green tea extract exhibit a nonsignificant decrease in theses markers compared to treatment with the other two extracts.

\section{Discussion}

Our current study demonstrated that STZ injection induced a significant hyperglycemia (increased serum glucose), hypoinsulinemia (decreased serum insulin), a poor glycemic control (increased $\mathrm{HbA1c}$ ) and insulin resistance (increased HOMA-IR), which may be due to dysfunction and destruction of insulin secretory cells (Akbarzadeh et al., 2007). In addition, The lipogram pattern of the STZ- diabetic rats showed significant changes indicated as an increases in serum TG, TC, LDL-C and calculated atherogenic index and a decrease in serum HDL-C compared to normal control group and this dyslipidemia may contribute to insulin resistance occurred in type 2 diabetes mellitus (American Diabetes Association, 2014). These findings were significantly reversed after treatment with catechins. Sundaram et al., (2013) suggested that the hypoglycemic effect of catechins is due to stimulation of glycogenesis and decreased glycogenolysis. Other studies revealed that in vitro, catechins can stimulate insulin secretion from isolated rat islets of Langerhans (Hii and Howell, 1984).

The elevations in serum glucose and free fatty acids that mostly occur in type 2 diabetes mellitus are thought to increase reactive oxygen species (ROS) levels (Evans et al., 2005; Folli et al., 2011), which in turn activate inflammation signaling pathways leading to insulin resistance (Muscogiuri et al., 2013). The inflammatory process triggers the release of pro-inflammatory cytokines such as tumor necrosis factor (TNF)- $\alpha$, interleukin (IL)-1 $\beta$ and IL-6. These cytokines will in turn trigger the production and secretion of acute phase proteins like C-reactive protein (CRP) and serum amyloid A (SAA) into the circulation (Badawi et al., 2010; Barbierato et al., 2017). Acute phase reactants are inflammatory markers and their serum concentration changed significantly during inflammation. CRP and SAA are positive acute phase reactants that are upregulated, and their serum concentrations elevated during inflammation (Gruys et al., 2005). CRP and SAA levels are increased after the destruction of insulin secretory cells in response to inflammation (Mao et al., 2017). The pro-inflammatory cytokines such as TNF- $\alpha$ and IL-6 are widely known markers of vascular inflammation (Rader, 2000; Singh et al., 2005). TNF- $\alpha$ reduces the insulin sensitivity because it decreases the expression of the insulin receptor IRS-1 and Glut-4. Also, TNF- $\alpha$ increases the phosphorylation of serine 307 in IRS-1, impairing its binding to the insulin receptor causing a downstream signaling (Rui et al., 2001). Additionally, the elevated levels of the circulating IL-6 is considered to be implicated in insulin resistance and $\beta$-cell dysfunction (Akbari and Hassan-Zadeh, 2018). Thus, TNF- $\alpha$, IL- 6 and CRP play an important role in insulin resistance and vascular inflammation through their multiple actions (Saghizadeh et al., 1996; Peraldi and 
Table 3: Effect of black tea, green tea and cocoa extracts on inflammatory markers in all groups.

\begin{tabular}{|c|c|c|c|c|}
\hline Groups & Serum CRP $(\mu \mathrm{g} / \mathrm{ml})$ & SAA level $(\mu \mathrm{g} / \mathrm{ml})$ & $\begin{array}{c}\text { Serum TNF- } \alpha \\
(\mathrm{pg} / \mathrm{ml})\end{array}$ & $\begin{array}{c}\text { Serum IL-6 } \\
(\mathrm{pg} / \mathrm{ml})\end{array}$ \\
\hline Normal control & $1.5 \pm 0.45$ & $6.5 \pm 1.8$ & $40.5 \pm 10.96$ & $48.9 \pm 14.0$ \\
\hline Black tea & $1.1 \pm 0.23$ & $6.3 \pm 1.2$ & $42.6 \pm 12.3$ & $46.8 \pm 15.7$ \\
\hline Green tea & $1.1 \pm 0.22$ & $5.5 \pm 1.5$ & $40.3 \pm 14.2$ & $47.8 \pm 18$ \\
\hline Cocoa & $1.09 \pm 0.21$ & $6.2 \pm 2.1$ & $42.6 \pm 13.5$ & $46.9 \pm 16.7$ \\
\hline Diabetic control & $4.5 \pm 1.6^{\#}$ & $52.1 \pm 19.7^{\#}$ & $78.93 \pm 12.4^{\#}$ & $182 \pm 23.4^{\#}$ \\
\hline $\begin{array}{l}\text { STZ-diabetic }+ \\
\quad \text { Black tea }\end{array}$ & $3.7 \pm 1.25^{*}$ & $27.5 \pm 6.0^{*}$ & $45.5 \pm 12.6^{*}$ & $116 \pm 19.3^{*}$ \\
\hline $\begin{array}{l}\text { STZ-diabetic + } \\
\text { Green tea }\end{array}$ & $3.5 \pm 1.0^{*}$ & $28 \pm 8.9^{*}$ & $46.4 \pm 12.03^{*}$ & $109 \pm 17.8^{*}$ \\
\hline $\begin{array}{c}\text { STZ-diabetic }+ \\
\text { Cocoa }\end{array}$ & $2.6 \pm 0.62^{* \$}$ & $22 \pm 7.5^{* \$}$ & $30.1 \pm 13.3^{* \$}$ & $105.5 \pm 18.3^{*}$ \\
\hline
\end{tabular}

Table 4: Effect of black tea, green tea and cocoa extracts on ASA production, OXO-LDL and serum NO in all groups.

\begin{tabular}{|c|c|c|c|}
\hline Groups & $\begin{array}{l}\text { ASA production (nmol cytochrome C } \\
\text { reduced/minutes/gm aortic tissue } \times 10^{-4} \text { ) }\end{array}$ & $\begin{array}{l}\text { OXO-LDL (nmol MDA/mg } \\
\text { non-HDL-C) }\end{array}$ & $\begin{array}{l}\text { Serum NO } \\
\text { level }(\mu \mathrm{mol} / \mathrm{L})\end{array}$ \\
\hline Normal control & $3.36 \pm 0.66$ & $89 \pm 15$ & $4.1 \pm 1.7$ \\
\hline Black tea & $3.22 \pm 0.83$ & $87 \pm 15.2$ & $3.7 \pm 1.12$ \\
\hline Green tea & $3.22 \pm 0.61$ & $88.9 \pm 14.8$ & $3.8 \pm 0.9$ \\
\hline Cocoa & $3.18 \pm 0.8$ & $89.8 \pm 17.9$ & $3.9 \pm 1.1$ \\
\hline Diabetic control & $6.38 \pm 1.05^{\#}$ & $246 \pm 40.6^{\#}$ & $18 \pm 4.9^{\#}$ \\
\hline $\begin{array}{l}\text { STZ-diabetic + } \\
\text { Black tea }\end{array}$ & $4.06 \pm 0.88^{*}$ & $125 \pm 28.8^{*}$ & $9.1 \pm 2.1^{*}$ \\
\hline $\begin{array}{l}\text { STZ-diabetic + } \\
\text { Green tea }\end{array}$ & $3.83 \pm 0.83^{*}$ & $123 \pm 15.8^{*}$ & $8.6 \pm 2.5^{*}$ \\
\hline $\begin{array}{l}\text { STZ-diabetic }+ \\
\text { Cocoa }\end{array}$ & $4.16 \pm 0.88^{*}$ & $123 \pm 18.5^{*}$ & $8.7 \pm 2.3^{*}$ \\
\hline
\end{tabular}


Spiegelman, 1998; Halse et al., 2001; Jialal et al., 2004; Wellen and Hotamisligil, 2005). Our results confirmed the previous illustration as TNF- $\alpha$, IL- 6 and CRP levels were significantly increased in STZ-diabetic rats compared to normal control group. While, treatment with catechins exhibit a certain degree of protection against vascular and inflammatory processes that cause diabetic complications. This has been evidenced by a significant decrease in serum CRP and SAA. Additionally, pro-inflammatory cytokines production TNF- $\alpha$ and IL- 6 were significantly decreased in diabetic rats which received catechins. Catechins target the components of proinflammatory signaling pathways whose expression is restricted and this attain a certain degree of protection (Trekli et al., 2004).

The production of ROS caused by hyperglycemia have also been implicated in the development of microvascular and macrovascular diabetic complications. As well, reaction of glucose with plasma proteins causes the formation of advanced glycation end products which stimulate the production of ROS. These ROS initiate a chain reaction leading to increasing production of nitric oxide (NO) and chemical modification of lipoproteins (Wrigh et al., 2006). The endothelial $\mathrm{NO}$ derived from the activation of constitutive NO synthase is essential for maintaining vascular homeostasis. However, higher concentrations of NO produced from immune cells such as macrophages by inducible nitric oxide synthase (iNOS) can cause oxidative damage. During inflammation, the greatly activated macrophages rise the simultaneous production of both NO and superoxide anions. NO reacts with superoxide anions free radicals, forming the highly damaging peroxynitrite which can directly oxidize low density lipoprotein causing irreversible damage (Babu and Liu 2008). Catechins may lower this oxidative stress by modifying the ROS generating enzymes such as iNOS. They can prevent the expression of iNOS in the activated macrophages by inhibiting the binding of nuclear transcriptional factor-kB (NF-kB) to the iNOS gene promoter and also they can reduce the activity of iNOS, therefor reducing toxic NO generation (Chan et al., 1997; Babu and Liu 2008) and this illustrated the potential antioxidant activity of catechins.

\section{Conclusions}

Our results indicated that tea and cocoa extracts contain some polyphenolic compounds such as catechins that had an anti-inflammatory, hypolipidemic, hypoglycemic and natural antioxidant effect on STZ diabetic rats.

Funding: No financial support was received.

Conflict of Interest: None of the authors have any conflicts of interest.

\section{References:}

Akbari, M., Hassan-Zadeh, V., 2018. IL-6 signaling pathways and the development of type 2 diabetes. Inflammopharmacology, 26, 685-698.

Akbarzadeh, A., Norouzian, D., Mehrabi, M.R., Jamshidi, S., Farhangi, A., Verdi, A.A., Mofidian, S.M.A., Rad, B.L., 2007. Induction of diabetes by Streptozotocin in rats. Indian J Clin Biochem, 22, 60-64.

Algandaby, M.M., Alghamdi, H.A., Ashour, O.M., Abdel-Naim, A.B., Ghareib, S.A., Abdel-Sattar, E.A., Hajar, A.S., 2010. Mechanisms of the antihyperglycemic activity of Retama raetam in streptozotocin-induced diabetic rats. Food Chem Toxicol, 48, 2448-2453.

Allain, C.C., Poon, L.S., Chan, C.S., Richmond, W., Fu, P.C., 1974. Enzymatic determination of total serum cholesterol. Clin Chem, 20, 470-475.

American Diabetes Association, 2014. Standards of medical care in diabetes. Diabetes Care, 37 (Suppl. 1), S14-S80.

Arts, I.C., van de Putte, B., Hollman, P.C., 2000. Catechin contents of foods commonly consumed in the Netherlands. 1. Fruits, vegetables, staple foods, and processed foods. J Agric Food Chem, 48, 1746-1751.

Auclair, C., Torres, M., Hakim, J., 1978. Superoxide anion involvement in NBT reduction catalyzed by NADPH-cytochrome P-450 reductase: A pitfall. FEBS Lett, 89, 26-28.

Babu, P.V., Liu, D., 2008. Green tea catechins and cardiovascular health: An update. Curr Med Chem, $15,1840-1850$.

Badawi, A., Klip, A., Haddad, P., Cole, D.E., Bailo, B.G., El-Sohemy, A., Karmali, M., 2010. Type 2 diabetes mellitus and inflammation: Prospects for biomarkers of risk and nutritional intervention. Diabetes Metab Syndr Obes, 3, 173186. 
Bahadoran, Z., Mirmiran, P., Azizi, F., 2013. Dietary polyphenols as potential nutraceuticals in management of diabetes: A review. J Diabetes Metab Disord, 12, 43.

Barbierato, M., Borri, M., Facci, L., Zusso, M., Skaper, S.D., Giusti, P., 2017. Expression and differential responsiveness of central nervous system glial cell populations to the acute phase protein serum amyloid A. Sci Rep, 7, 12158.

Bhardwaj, P., Khanna, D., Balakumar, P., 2014. Catechin averts experimental diabetes mellitusinduced vascular endothelial structural and functional abnormalities. Cardiovasc Toxicol, 14, 41-51.

Bhattacharya, S., 2017. Medicinal plants and natural products in amelioration of arsenic toxicity: A short review. Pharm Biol, 55, 349-354.

Bryan, N.S., Grisham, M.B., 2007. Methods to detect nitric oxide and its metabolites in biological samples. Free Radic Biol Med, 43, 645-657.

Chan, M.M., Fong, D., Ho, C.T., Huang, H.I., 1997. Inhibition of inducible nitric oxide synthase gene expression and enzyme activity by epigallocatechin gallate, a natural product from green tea. Biochem Pharmacol, 54, 1281-1286.

Chen, H., Liu, L., Zhu, J., Xu, B., Li, R., 2010. Effect of soybean oligosaccharides on blood lipid, glucose levels and antioxidant enzymes activity in high fat rats. Food Chemistry, 119, 1633-1636.

Dey, P., Chandra, S., Chatterjee, P., Bhattacharya, S., 2011. Neuropharmacological properties of Mikania scandens (L.) Willd. (Asteraceae). J Adv Pharm Technol Res, 2, 255-259.

Doctrow, S.R., Huffman, K., Marcus, C.B., Musleh, W., Bruce, A., Baudry, M., Malfroy, B., 1997. Salen-manganese complexes: combined superoxide dismutase/catalase mimics with broad pharmacological efficacy. Adv Pharmacol, 38, 247269.

Evans, J.L., Maddux, B.A., Goldfine, I.D., 2005. The molecular basis for oxidative stress-induced insulin resistance. Antioxid Redox Signal, 7, 10401052.

Folli, F., Corradi, D., Fanti, P., Davalli, A., Paez, A., Giaccari, A., Perego, C., Muscogiuri, G., 2011. The role of oxidative stress in the pathogenesis of type 2 diabetes mellitus micro-and macrovascular complications: Avenues for a mechanistic-based therapeutic approach. Curr Diabetes Rev, 7, 313324.

Fossati, P., Prencipe, L., 1982. Serum triglycerides determined colorimetrically with an enzyme that produces hydrogen peroxide. Clin Chem, 28, 20772080.

Friedewald, W.T., Levy, R.I., Fredrickson, D.S., 1972. Estimation of the concentration of lowdensity lipoprotein cholesterol in plasma, without use of the preparative ultracentrifuge. Clin Chem, $18,499-502$.

Gruys, E., Toussaint, M.J., Niewold, T.A., Koopmans, S.J., 2005. Acute phase reaction and acute phase proteins. J Zhejiang Univ Sci B, 6, 1045-1056.

Halse, R., Pearson, S.L., McCormack, J.G., Yeaman, S.J., Taylor, R., 2001. Effects of tumor necrosis factor-alpha on insulin action in cultured human muscle cells. Diabetes, 50, 1102-1109.

Hii, C.S., Howell, S.L., 1984. Effects of epicatechin on rat islets of Langerhans. Diabetes, 33, 291-296.

Jaiswal, Y.S., Tatke, P.A., Gabhe, S.Y., Vaidya, A.B., 2016. Antidiabetic activity of extracts of Anacardium occidentale linn. leaves on nstreptozotocin diabetic rats. J Tradit Complement Med, 7, 421-427.

Jialal, I., Devaraj, S., Venugopal, S.K., 2004. Creactive protein: Risk marker or mediator in atherothrombosis? Hypertension, 44, 6-11.

Kofink, M., Papagiannopoulos, M., Galensa, R. 2007. (-)-Catechin in Cocoa and Chocolate: Occurence and Analysis of an Atypical Flavan-3-ol Enantiomer. Molecules, 12, 1274-1288.

Lopes-Virella, M.F., Stone, P., Ellis, S., Colwell, J.A., 1977. Cholesterol determination in highdensity lipoproteins separated by three different methods. Clin Chem, 23, 882-884.

Majchrzak, D., Mitter, S., Elmadfa, I., 2004. The effect of ascorbic acid on total antioxidant activity of black and green teas. Food Chemistry, 88, 447451.

Mao, J.Y., Sun, J.T., Yang, K., Shen, W.F., Lu, L., Zhang, R.Y., Tong, X., Liu, Y., 2017. Serum amyloid A enrichment impairs the antiinflammatory ability of HDL from diabetic 
nephropathy patients. J Diabetes Complications, 31, 1538-1543.

Matthews, D.R., Hosker, J.P., Rudenski, A.S., Naylor, B.A., Treacher, D.F., Turner, R.C., 1985. Homeostasis model assessment: insulin resistance and beta-cell function from fasting plasma glucose and insulin concentrations in man. Diabetologia, 28, 412-419.

Montonen, J., Knekt, P., Järvinen, R., Reunanen, A., 2004. Dietary antioxidant intake and risk of type 2 diabetes. Diabetes Care, 27, 362-366.

Muscogiuri, G., Salmon, A.B., Aguayo-Mazzucato, C., Li, M., Balas, B., Guardado-Mendoza, R., Giaccari, A., Reddick, R.L., Reyna, S.M., Weir, G., Defronzo, R.A., Remmen, H.V., Musi, N., 2013. Genetic disruption of SOD1 gene causes glucose intolerance and impairs $\beta$-cell function. Diabetes, 62, 4201-4207.

Musleh, W., Bruce, A., Malfroy, B., Baudry, M., 1994. Effects of EUK-8, a synthetic catalytic superoxide scavenger, on hypoxia- and acidosisinduced damage in hippocampal slices. Neuropharmacology, 33, 929-934.

Ohkawa, H., Ohishi, N., Yagi, K., 1979. Assay for lipid peroxides in animal tissues by thiobarbituric acid reaction. Anal Biochem, 95, 351-358.

Othman, A., Ismail, A., Ghani, N.A., Adenan, I., 2007. Antioxidant capacity and phenolic content of cocoa beans. Food Chemistry, 100, 1523-1530.

Pandey, K.B., Rizvi, S.I., 2009. Plant polyphenols as dietary antioxidants in human health and disease. Oxid Med Cell Longev, 2, 270-278.

Peraldi, P., Spiegelman, B., 1998. TNF- $\alpha$ and insulin resistance: Summary and future prospects. Mol Cell Biochem, 182, 169-175.

Pourcyrous, M., Leffler, C.W., Bada, H.S., Korones, S.B., Busija, D.W., 1993. Brain superoxide anion generation in asphyxiated piglets and the effect of indomethacin at therapeutic dose. Pediatr Res, 34, 366-369.

Rader, D.J., 2000. Inflammatory markers of coronary risk. New Engl J Med, 343, 1179-1182.

Rahimi, R., Nikfar, S., Larijani, B., Abdollahi, M., 2005. A review on the role of antioxidants in the management of diabetes and its complications. Biomed Pharmacother, 59, 365-373.
Reed, M.J., Meszaros, K., Entes, L.J., Claypool, M.D., Pinkett, J.G., Gadbois, T.M., Reaven, G.M., 2000. A new rat model of type 2 diabetes: the fatfed, streptozotocin-treated rat. Metabolism, 49, 1390-1394.

Rinaldo, D., Batista, J.M., Rodrigues, J., Benfatti, A.C., Rodrigues, C.M., dos Santos, L.C., Furlan, M., Vilegas, W., 2010. Determination of catechin diastereomers from the leaves of Byrsonima species using chiral HPLC-PAD-CD. Chirality, 22, 726-733.

Rossini, A.A., Like, A.A., Chick, W.L., Appel, M.C., Cahill, G.F., 1977. Studies of streptozotocininduced insulitis and diabetes. Proc Natl Acad Sci U S A, 74, 2485-2489.

Rui, L., Aguirre, V., Kim, J.K., Shulman, G.I., Lee, A., Corbould, A., Dunaif, A., White, M.F., 2001. Insulin/IGF-1 and TNF-alpha stimulate phosphorylation of IRS-1 at inhibitory Ser307 via distinct pathways. J Clin Invest, 107, 181-189.

Saghizadeh, M., Ong, J.M., Garvey, W.T., Henry, R.R., Kern, P.A., 1996. The expression of TNF alpha by human muscle. Relationship to insulin resistance. J Clin Invest, 97, 1111-1116.

Singh, U., Devaraj, S., Jialal, I., 2005. Vitamin E, oxidative stress and inflammation. Ann Rev Nutr, $25,151-174$

Srinivasan, K., Viswanad, B., Asrat, L., Kaul, C.L., Ramarao, P., 2005. Combination of high-fat dietfed and low-dose streptozotocin-treated rat: a model for type 2 diabetes and pharmacological screening. Pharmacol Res, 52, 313-320.

Sundaram, R., Naresh, R., Shanthi, P., Sachdanandam, P., 2013. Modulatory effect of green tea extract on hepatic key enzymes of glucose metabolism in streptozotocin and high fat diet induced diabetic rats. Phytomedicine, 20, 577584.

Trekli, M., Buttle, D., Guesdon, F., 2004. Antiinflammatory actions of green tea catechins and ligands of peroxisome proliferator-activated receptors. Int J Exp Pathol, 85, A75.

Trinder, P., 1969. Determination of blood glucose using 4-amino phenazone as oxygen acceptor. J Clin Pathol, 22, 246.

Vuong, Q.V., Golding, J.B., Stathopoulos, C.E., Nguyen, M.H., Roach, P.D., 2011. Optimizing 
conditions for the extraction of catechins from green tea using hot water. J Sep Sci, 34, 3099-3106.

Wang, H.D., Pagano, P.J., Du, Y., Cayatte, A.J., Quinn, M.T., Brecher, P., Cohen, R.A., 1998. Superoxide anion from the adventitia of the rat thoracic aorta inactivates nitric oxide. Circ Res, 82, 810-818.

Wein, S., Beyer, B., Gohlke, A., Blank, R., Metges, C.C., Wolffram, S. 2016. Systemic Absorption of Catechins after Intraruminal or Intraduodenal Application of a Green Tea Extract in Cows. Plos
One, 1-17. DOI:10.1371/journal.pone.0159428

Wellen, K.E., Hotamisligil, G.S., 2005. Inflammation, stress, and diabetes. J Clin Invest, $115,1111-1119$.

Wright, E., Jr, Scism-Bacon, J.L., Glass, L.C., 2006. Oxidative stress in type 2 diabetes: The role of fasting and postprandial glycaemia. Int $\mathbf{J}$ Clin Pract, 60, 308-314.

Yilmaz, Y., 2006. Novel uses of catechins in foods. Trends Food Sci.Tech, 17, 64-71. 